\title{
Policy Development of River Water Quality Governance Toward Land Use Dynamics Through a Risk Management Approach
}

\author{
Idi Namara' ${ }^{1}$ Djoko M. Hartono ${ }^{\prime *}$, Yusuf Latief', Setyo Sarwanto Moersidik' \\ 1 Civil Engineering Department, Universitas Indonesia, Depok, West Java, 16424, Indonesia \\ * Corresponding author's e-mail: djokomh@eng.ui.ac.id
}

\begin{abstract}
The Cisadane River, Tangerang City, is one of the most important rivers in Indonesia. This river provides raw water for Municipal Waterworks (PDAM) of the Tangerang City and Soekarno-Hatta International Airport, but the water quality tends to deteriorate due to pollution. The government has made various efforts to manage the river water quality, but no significant resolution was issued yet. The problem is becoming more complicated due to landuse changes that affect the pollutant load. Therefore, more precise, integrated, and comprehensive management is needed. This study used an approach with various methodologies according to the stages of the research, including; qualitative and quantitative analysis, GIS, statistics, risk management, and System Dynamic. The outcome of this research was the development of the policies in river water quality management, specifically land use management, separation of drainage channels from domestic sewage channels, enhancement of Wastewater Treatment Plant (WWTP) services coverage, as well as reinforcement of institutional and regulatory aspects, especially in funding commitments.
\end{abstract}

Keywords river water pollution, land use, physical project approach, wwtp and drainage, legal and institutional aspects, risk management and system dynamic.

\section{INTRODUCTION}

The Cisadane River is the icon of the Tangerang City as a Water Front City. Moreover, this river provides raw water for Municipal Waterworks (PDAM) to meet the needs of clean water of Tangerang City. Soekarno-Hatta International Airport has also made the Cisadane River water a source of raw water. Most of the industries in the Tangerang City utilize the Cisadane River water in their activities, but the river water has become severely polluted in recent years (Namara, 2017). On the basis of the 2015-2019 National Medium-Term Development Plan (RPJMN), the Cisadane Watershed (DAS), where the Cisadane River is located, constitutes 1 of 15 priority watersheds in Indonesia. This river stretches across the Tangerang City for $15 \mathrm{~km}$.

The Tangerang city is one of the notable cities in Indonesia; its vast development, along with considerable population growth generates new residential areas and industrial growth. This development has resulted in changes in land use, which in turn could increase the pollutant load, especially in the Cisadane watershed of the Tangerang City. On the basis of the BPS data from 1991 to 2015, the changes in the open land into developed land (industrial areas, offices, and residential areas) reached nearly 4,000 hectares. Figure 1 shows the trend of land change in the Tangerang City.

The research conducted by Suwari (2011) explained that land-use change could negatively affect in high pollutant load. The results of other studies related to city development in Vietnam also emphasized the impact of urban development on the depletion of surface water quality and increased wastewater production as the population grows (Mihn, 2011). The research by Huang (2013) also explained that rapid land-use changes degrade the river water quality.

The government has made various efforts, but no significant resolution was issued yet. A construction-based approach was conducted with the 


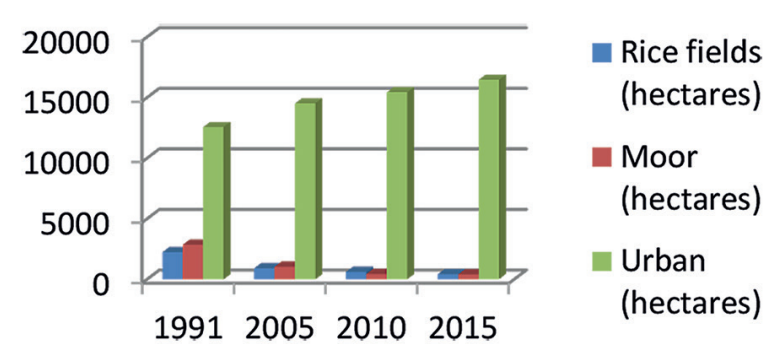

Figure 1. Rate of change in land use

construction of ridge, retaining walls, normalization, and green spaces, but the river water quality has not improved significantly. Other approaches include issuing local regulations regarding water quality management, strengthening the institutional aspects of institutions that are concerned with river problems, and managing wastewater in watershed areas. None of these efforts have shown positive results for changes in water quality. The problem is becoming more complicated with the lack of WWTP services coverage in the watershed area, which only reaches 5\%. Also, domestic sewerage channels and drainage channels are fused. This study aimed to identify the important factors in river water quality management, arrange a governance scenario with a Risk Management approach, then develop a Model using System Dynamic. More effective governance is expected to change in the management of river water quality as a source of raw water in Indonesia. The risk management approach is expected to minimize the foibles of the implementation of various management measures, as well as maximize the positive impact.

\section{MATERIALS AND METHODS}

This research uses various approaches, initiated with the identification of key factors in water quality management using literature review methods and regulatory studies, then an assessment of the implemented management conducted and a governance scenario was determined all together based on the key factors identified through the risk management approach. The governance strategy was formed into a River Water Quality Management Policy Development Model, using a System Dynamic approach. The following Figure 2 explains the stages in the research conducted.

\section{Literature review}

Other important aspects of river water quality management are regulatory and institutional aspects. The studies conducted by Barqawi (2008), Gyawali (2013), and Namara (2018) determined the role of the government along with handling and policy priorities. Public participation is also necessary for river management. Thus, this participation will be optimized with strong law enforcement or regulations.

Another aspect is the problem of wastewater management and drainage networks in the watershed area. The research in Turkey, Gulbaz (2012) explained that drainage channels affect the river water pollution, especially the TSS (Total Suspended Solid) parameter will be higher in congested areas, particularly in waterways at every road intersection. Heinemen (2013) stated that the drainage channel could be a complete hydraulic representation of a natural drainage system and city development with a dynamic water quality process simulation can improve the water quality (Heineman, 2013). Concerning the function of drainage as storage for rainwater runoff, it will certainly help the process of improving the water quality, especially if the drainage channel used is environmentally friendly drainage or eco-drain. The research by Mangangka

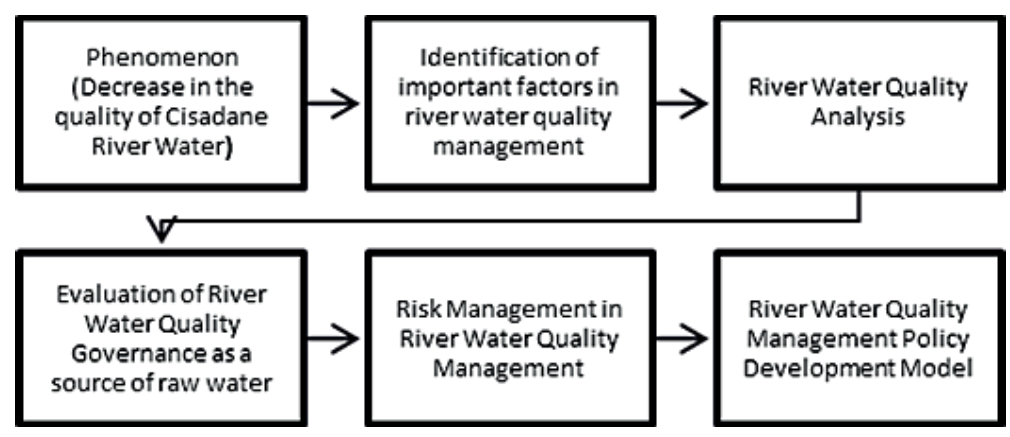

Figure 2. Stages of research 
(2016) showed that Constructed Wetland could be used as an eco-drain component affecting the river water quality. The importance of treating wastewater before discharge into the environment or water bodies was emphasized. Improper implementation of the wastewater management system would degenerate the river water quality (Ray, 2010).

\section{System dynamics modeling}

The complicated problem of river quality management requires thorough and multidimensional handling methods. As happened in China, the problem of sustainable use of water resources in urban areas is complicated, because it includes the spatio-temporal processes that are influenced by natural, social, and economic factors (Fan, 2009), solving the problem with System Dynamic implementation. The output is a model that is considered decently applicable; in turn (Mirchi, 2012) states that the System Dynamic is a model that facilitates the application of systems thinking and holistic conceptualization, especially in water resource systems. The application of System Dynamic in water resources engineering and management have grown over the past two decades (Inez, 2009). System Dynamic is defined as a method for studying complex, dynamic, non-linear systems through feedback management. The System Dynamic approach focuses on the structure and behavior of a system constructed from interacting feedback (Sterman, 2004). System Dynamic considers problems multidimensionally and from various points of view, the causal relationship could be explained clearly through this method (Soesilo, 2014). A similar conception was expressed by Zhihe (2014), which stated System Dynamic is a qualitative and quantitative research method that includes integrated analysis and simulation systems.

\section{Risk management approach}

In PMBOK Fifth Edition. 2013, risk management is a systematic process in identifying, analyzing, and resolving risk problems that will occur in a project or project activity; in this case, the governance of river water quality, including optimizing the probability and consequences of positive occurrences and minimizes the probability and consequences of adverse occurrences for the objectives of the project or activity
(Sanchez, 2013). The existing governance of water quality of the Cisadane River has not shown any improvement in this parameter. With a risk management approach, the governance is expected to optimize the positive impact of the various approaches implemented, while minimizing the negative impact or failure.

Thus, by combining the Dynamic System approach with risk management, it is intended to become the leading model in river water quality management. This research is expected to provide the solutions to river water quality management due to land-use changes in the watershed area. This combination created an intervention model that comprises structural and functional quality. This Risk Managementbased System Dynamic method develops the existing solutions to optimize functions, provide structural solutions or new interventions that do not exist yet.

\section{RESEARCH RESULT}

\section{Identification of key factors}

Identification of key factors in river water quality management was carried out based on related regulations, compared with 30 previous relevant studies. The regulations are Government Regulation No 42 of 2008 concerning Management of Water Resources; Government Regulation No. 38 of 2011 concerning Rivers; Government Regulation No. 82 of 2001 concerning Management of Water Quality and Water Pollution Control. Through the conducted study, 6 key factors in the management of river water quality were determined. Figure 3 explained the six key factors.

Those six factors are variables in the development of management-based governance. The research conducted by Namara (2020) analyzed the river water quality using data from the Environmental Agency of Tangerang City from 2010 to 2015 , complemented by the results of sampling tested at the University of Indonesia Environmental Engineering Laboratory in 2016. There are 16 sampling locations along the $15 \mathrm{~km}$ of river length. The analysis of the water quality status was conducted using the Storet method. The results obtained from all sample locations showed that the river was in heavily polluted conditions. 


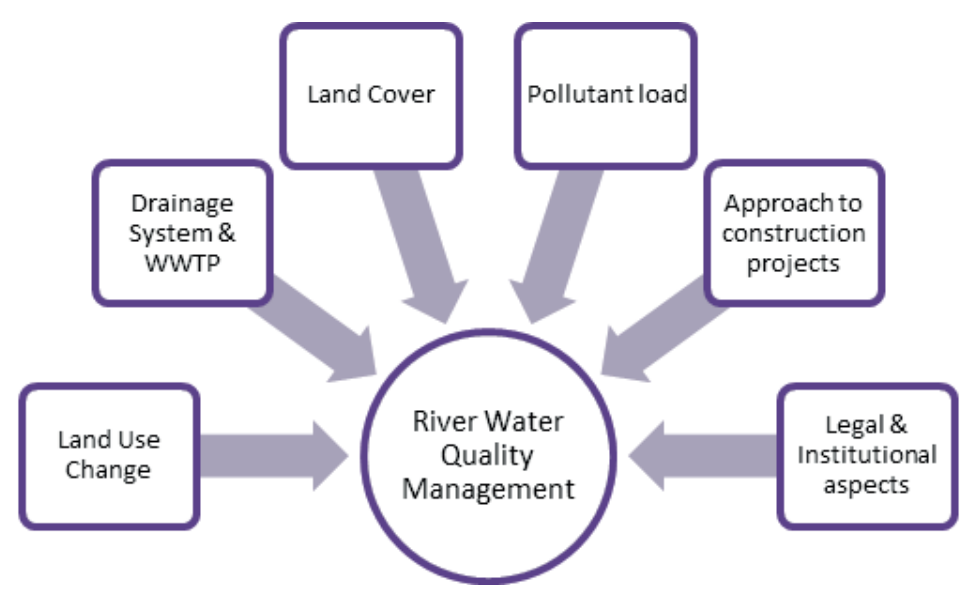

Figure 3. Key factors in river water quality management

\section{Risk management analysis}

On the basis of the discussion above, 6 variables in river water quality management related to land-use changes were obtained. Those variables are interrelated and contribute significantly to the success of river water quality management. Those variables were analyzed using a risk management approach to optimize positive impact and anticipate the failures in managing the river water quality.

The Risk Management study and assessment was conducted with 4 resource persons: 1) the Head of the Cidurian-Cisadane River Basin Management Organization (BBWS), Banten Province; 2) the Head of the Technical Operations Division of Ciliwung-Cisadane River Basin Management Organization (BBWS), Directorate General of Water Resources, the Ministry of Public Works and Public Housing; 3) the Head Technical Division of the Environmental Agency (BLH) in Tangerang City; and 4) the Head of the Water Quality Standard Section, Directorate of Pollution Control, Ministry of Environment \& Forestry. The initial stage is to identify the possible risks based on the variables.

The risk identification of the variables resulted in 34 possible risks. Identification also aimed to anticipate and solve the risks. The analysis was conducted through a risk register. At this stage, the researcher and 4 resource persons conducted a separate assessment simultaneously. The assessment results were rounded off on average. The assessment resulted in 15 priority risks, from 34 identified risks. The priority risks are shown in Table 1.

The risk priority was also assessed by Expert judgment to ascertain the analysis results. Expert
1 is a professor of Water Resources at Diponegoro University, Semarang (Prof. Dr. Suripin, M. Eng) and Expert 2 is a professor of Water Resources at the Universitas Indonesia (Prof. Dr. Ing. Dwita Sutjiningsih, Dipl Ing).

On the basis of the results of the validated risk priority analysis, a policy development strategy in the management of river water quality as a source of raw water was determined, by strengthening the implementation of existing policies, so it could be implemented properly, effectively, and optimally, including:

1. Strengthening the implementation of the landuse plan (RTRW) for Tangerang City. On the basis of Law No. 26 of 2007, the minimum area of open land (or RTH) is 30. In 2016, the area of open land was $29.87 \%$. Considering that the changes in land use will continue to occur due to population growth and economic activity, the commitment to preserve and maintain the ratio of developed land to open land is needed, as well as ensuring the requirements in constructing supporting infrastructure, especially for handling wastewater and solid waste in land development.

2. Separating drainage channels (rainwater runoff) and domestic wastewater drain completely. Indirectly, this could increase the coverage of WWTP services (increasing capacity for City-Scale WWTP) and maximizing service levels for city-scale WWTP. Moreover, Communal WWTP in residential areas should be constructed.

3. Strengthening coordination among related institutions, from central, provincial to city government levels, to optimize and synergize various programs in river water quality management. 
Table 1. Priority risks

\begin{tabular}{|c|c|c|}
\hline No & Risk description & Severity \\
\hline 1 & $\begin{array}{l}\text { The growth of developed land } \\
\text { contribute to the degradation of river } \\
\text { water quality. }\end{array}$ & 0.56 \\
\hline 2 & Population growth worsen pollution. & 0.56 \\
\hline 3 & $\begin{array}{l}\text { The related regulations had not } \\
\text { socialized effectively to the public. }\end{array}$ & 0.56 \\
\hline 4 & $\begin{array}{l}\text { WWTP service coverage in the city } \\
\text { scale is }<2 \% \text {. }\end{array}$ & 0.49 \\
\hline 5 & $\begin{array}{l}\text { The pollutant load from the river } \\
\text { upstream and South Tangerang City is } \\
\text { very impactful to water quality. }\end{array}$ & 0.49 \\
\hline 6 & $\begin{array}{l}\text { The use of land for residential areas } \\
\text { generates waste. }\end{array}$ & 0.49 \\
\hline 7 & $\begin{array}{l}\text { The river water quality in } 2010-2016 \\
\text { was categorized as heavily polluted. }\end{array}$ & 0.49 \\
\hline 8 & $\begin{array}{l}\text { Changing open land into residential } \\
\text { areas degenerates water quality. }\end{array}$ & 0.49 \\
\hline 9 & $\begin{array}{l}\text { Changing open land into industrial } \\
\text { areas degenerate water quality. }\end{array}$ & 0.49 \\
\hline 10 & $\begin{array}{l}\text { The construction sector development } \\
\text { reduces open land. }\end{array}$ & 0.49 \\
\hline 11 & Industrial use of land generates waste. & 0.40 \\
\hline 12 & $\begin{array}{l}\text { The discharge of wastewater from } \\
\text { drainage affects the river water quality. }\end{array}$ & 0.40 \\
\hline 13 & $\begin{array}{l}\text { River management is dominated } \\
\text { by the River Basin Management } \\
\text { Organization (BBWS / BWS) cc } \\
\text { Ministry of Public Works and Public } \\
\text { Housing. }\end{array}$ & 0.40 \\
\hline 14 & High domestic pollution load. & 0.30 \\
\hline 15 & $\begin{array}{l}\text { Ridge and retaining wall not } \\
\text { functioning optimally. }\end{array}$ & 0.24 \\
\hline
\end{tabular}

Source: Analysis Results, 2018-2019.

4. Strengthening the implementation of existing regulations, providing a strong legal basis to execute the workplan (related to commitments in budgeting or funding) and assert the application of sanctions against the stakeholders that do not participate in river water quality management and pollution control.

5. Increasing community participation in water quality management and pollution control, and socializing the existing regulations optimally to raise public awareness of the river water quality management issues.

\section{System dynamic governance model}

From the previous description, 15 priority risks were determined, strengthened by Expert Judgment and expert validation, thus becoming the basis for developing policies in river water quality management. This governance policy development became the basis for structuring the problem system. The Story is arranged based on the description of the problem system structure.
Table 2 explains the variables and operational definitions and the Story output in the management of the Cisadane river water quality which is simplified into 9 loops.

\section{Story and causal loop diagram}

Population growth is in line with or mutually affecting growth in residential areas (R1), along with population growth industry areas also grow, thus job opportunity arises. (R2).

More population means more extensive needs in wastewater treatment. Thus, the service coverage of WWTP must expand and prevent river pollution. Controlled pollution will affect the river water quality. A clean and unpolluted river will have a beneficial impact on population growth (R7).

The population growth will increase the residential areas, potentially polluting the river and deteriorating the river water quality. The river water quality problems affect the population growth (B3).

The population growth will increase the residential areas, potentially polluting the river and deteriorating the river water quality. The river water quality problems affect the population growth (B4).

The population growth will stimulate the growth in industrial areas. The growth in industrial areas will further reduce the open land. Meanwhile, open land significantly affects river pollution control. However, river pollution deteriorates the river water quality, which in turn affects the population (B5).

The population growth will stimulate the growth in residential areas. The growth in residential areas will further reduce the open land. Meanwhile, open land significantly affects river pollution control. However, river pollution deteriorating the river water quality, which in turn affects the population (B6).

Higher river pollution requires wastewater management, thus WWTP with optimal function has to be constructed to minimize river pollution (B8).

In the last story, public participation in river water quality management is expected. With the regulation socialization, supposedly public will implement the regulations in waste management, thus reducing the pollution load (B9).

On the basis of the stories, the explanation of the variables and the operational definitions of the 
Table 2. Variables and operational definition of variables

\begin{tabular}{|c|l|l|c|}
\hline No & \multicolumn{1}{|c|}{ Variable } & \multicolumn{1}{c|}{ Operational Definition of Variables } & Variable Unit \\
\hline 1 & Land-use change & Area of open land that changes into developed land & Ha \\
\hline 2 & Industrial area growth & Area of industrial growth & Ha \\
\hline 3 & Residential area growth & Area of residential growth & Peoples / year \\
\hline 4 & Population growth & Population growth in a city area & House conncetion \\
\hline 5 & WWTP & Number of WWTP joints and service coverage & mg/L \\
\hline 6 & WWTP needs & Number of houses in the watershed area & $\%$ \\
\hline 7 & River pollutant load & $\begin{array}{l}\text { Pollution load that affects water quality, 2 parameters } \\
\text { (BOD and COD) }\end{array}$ & Rupiah / year \\
\hline 8 & Public participation & $\begin{array}{l}\text { Percentage of public awareness and participation level } \\
\text { in river management }\end{array}$ & Level 1-4 \\
\hline 10 & Regulatory and institutional & $\begin{array}{l}\text { Budget funds commitment to construct river water } \\
\text { quality management infrastructure }\end{array}$ & Water quality \\
\hline
\end{tabular}

Source : Analysis Results, 2018-2019

variables, a basic model is developed (CLD) in the Development of Water Quality Governance Policy. Figure 4 shows a river water quality management model.

\section{Prediction analysis of system performance without intervention (business as usual)}

Using the initial model built, the following is a prediction of system performance without intervention for the next 9 years (2020-2028). The results of the analysis of the model show that in 2028, the pollution load is worsened, without any intervention. In 2010, BOD concentration was $8.28 \mathrm{mg} / 1$ (water quality standard class 4 ) and would reach $68.09 \mathrm{mg} / \mathrm{l}$ in 2029 (exceed water quality standard class 4$)$. The COD concentration was initially $32.12 \mathrm{mg} / 1$ (water quality standard class 3), in 2029 it would be $58.33 \mathrm{mg} / 1$ (water quality standard class 4 ). Figure 5 describes the pollution conditions of the Cisadane River in the Tangerang City for BOD and COD parameters.

\section{Analysis of system performance with intervention}

The results of the analysis of the model built shown that if the intervention scenario implementation resulted in reducing the pollution load. With this intervention, the BOD concentration that was initially $8.28 \mathrm{mg} / 1$ (standard water, while for COD the initial concentration was $32.12 \mathrm{mg} / \mathrm{l}$ (standard water quality class 3 ) and in 2029 it decrease would decrease to $25.5 \mathrm{mg} / 1$ (almost meeting the standard water quality class 2). Figure 6 shows a graph of the reduction in pollution of the Cisadane River in the Tangerang

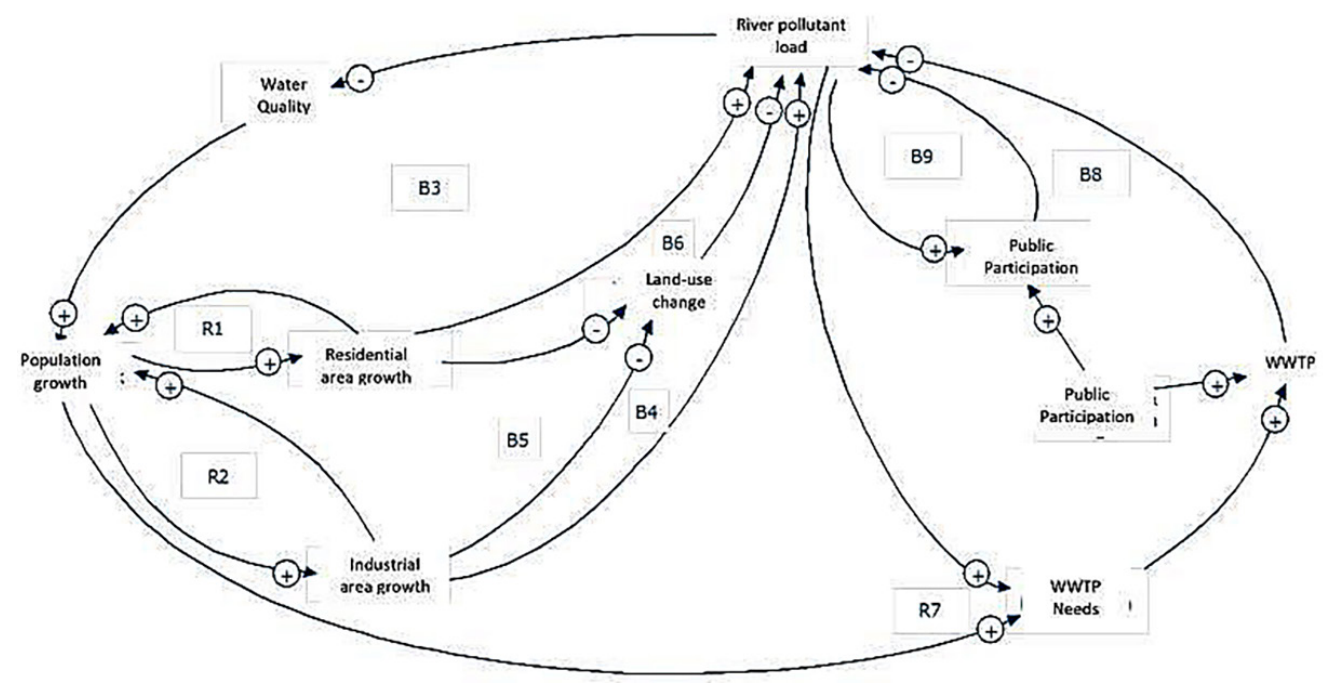

Figure 4. River water quality management model 

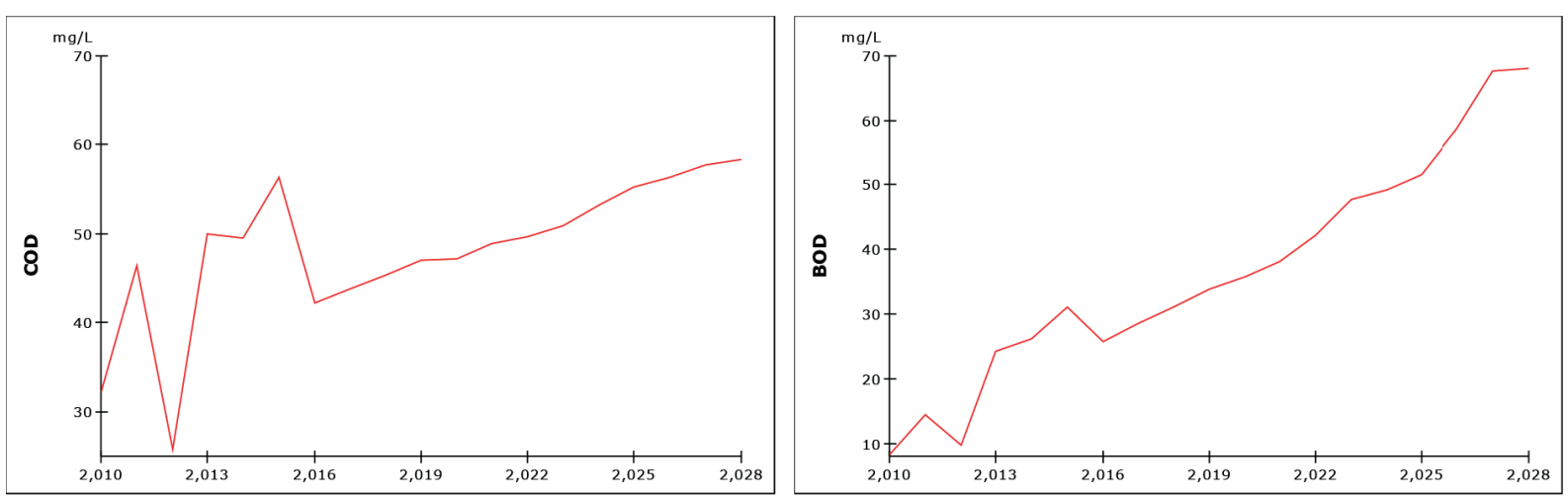

Figure 5. Graph of river pollution (COD \& BOD) without intervention scenarios

City (BOD \& COD parameters) with the intervention scenario.

The intervention conducted including strengthening the institutional and regulatory aspects, especially related to the integration of river management programs, and also committed budget funds to construct WWTP and house connections (SR) of 289,224 thus the WWTP service coverage close to $100 \%$. The improvement in WWTP, including separate drainage channels from sewage channels. The budget funds required for 9 years (2020-2028) is 1.446 trillion Rupiah. The constant growth of public participation until 2028 is $60 \%$. Figure 6 below shows the trend of declining pollution concentration of BOD and COD parameters.

\section{RESULT AND DISCUSSION}

Development of the policy formulated was based on risk management of river water quality governance. Systematically, the identification of possible risks has been conducted, priority risks were determined, and the responses needed were resolved. Initially, the analysis was conducted to the river that stretches for $15 \mathrm{~km}$ across the Tangerang City; it is in the heavily polluted category. The analysis conducted using the STORET method based on 2010-2016 data showed a decreasing trend in the river water quality. The decline in river water quality is reciprocal with land-use changes in the Cisadane watershed area of the Tangerang City. The population increase and economic growth in the Tangerang City resulted in the expansion of residential and industrial areas. The previous analysis stated that the reduction in open land and an increase of industrial areas in the watershed area contributed to decreasing river water quality.

The construction project approaches, including the construction of the riparian area, green open space and riverside parks, ridge and retaining walls, as well as river normalization were conducted progressively. As a waterfront city, the Cisadane River is one of the icons for the Tangerang City. The construction project approach only gives a clean and beautiful impression, but it is not in line with the quality of river water, every year the quality of river water tends to decline and is categorized as heavily polluted.
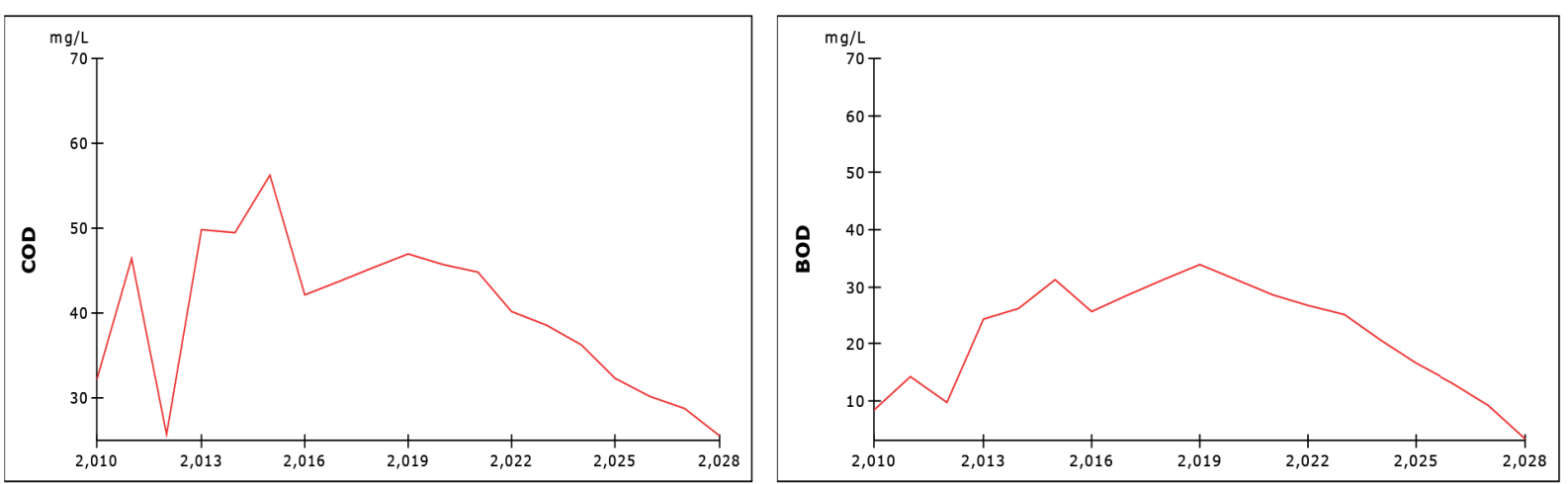

Figure 6. Graph of river pollution conditions with intervention scenarios 
The flow from drainage channels also increases the load of river pollution, because domestic wastewater channels and drainage channels are joined. The separation between the domestic wastewater channel and the drainage channel needs to be prioritized and implemented under the existing regulations. Parallel to the dual function of drainage channels, the WWTP of the Tangerang City is only able to accommodate $0.67 \%$ of service coverage, or if the watershed area is narrowed down, service coverage only reaches more than $5 \%$. Since the WWTP service capacity is limited, the public is accustomed to discharging wastewater directly into the drainage channel. It needs commitment and affirmation in implementing the separation of drainage channels from domestic wastewater channels. Currently, the WWTP capacity is very limited; according to the existing regulations, more units and capacities are needed, whereas the government is obliged to provide integrated sanitation facilities and infrastructure.

For the institutional aspect, even at the central government level, there is the Ciliwung Cisadane River Basin Management Organization (BBWS) of the Directorate General of Water Resources of the Ministry of Public Works and Public Housing, but there are limitations in budget, personal competency, and work plans. Likewise, at Banten Province, even the Cidurian Cisadane Water Resources Management Organization is not authorized to carry out development programs. Meanwhile, at the city government level, several institutions are involved in governance. At least 6 offices of city-level government have respective duties and functions in the management of the Cisadane River in the Tangerang City.

For regulatory aspects, regulation in the central level (government regulations), provincial and city governments, have been issued. This regulation needs to be introduced optimally to the public. The public also needs to be involved in the implementation of the regulations. Coordination between institutions at various levels needs to be strengthened to ensure that river management is integrated and systematized. The existing institutions integrated with an adequate legal basis have become the resources to strengthen the budget (budget state and local government budget) in implementing river water quality governance.

\section{CONCLUSIONS}

The governance model built showed an improvement in river water quality, by strengthening the regulatory and institutional aspects, in the form of integrated programs that require a budget of IDR 1.446 trillion for 9 years (2020-2028) to construct WWTP to serve $100 \%$ resident in the DAS region or 289,224 house connections (HC). The improvement of domestic waste treatment services indirectly separates the sewerage from the drainage channel, followed by $60 \%$ public participation in taking an active role in maintaining the cleanliness of the river, so the water quality of the Cisadane River will be improved, reaching the standard water quality class 2 level or clean water standards by 2029 .

\section{Acknowledgements}

The authors would like to acknowledge funding support from the Universitas Indonesia PUTI DOKTOR 2020 grant in this research.

\section{REFERENCES}

1. Azadeh A., Laramaoz M., Moridi A., Han D. 2012. Integrated planning of land use and water allocation on a watershed scale considering social and water quality issues. Journal of Water Resources Planning and Management.

2. Barqawi A.H., Zayed T. 2008. Infrastructure management: Integrated AHP/ANN model to evaluate municipal water mains' performance. Journal of Infrastructure System.

3. Mangangka I.R., Wuisan E.M. 2016. Assessing Constructed Wetland Treatment Performance. Book Chapter 4, Springer International.

4. Qingxin F., Ying L., Nanqi R. 2009. Application of system dynamics in analyzing the water environment system: A case study of Harbin City. IEEE.

5. Gulbaz S., Kazezyilmaz Alhan C.M. 2012. Impact of land use/cover changes on water quality andquantity in a calibrated hydrodynamic model. 10th International Congress on Advances in Civil Engineering (ACE 2012), Ankara.

6. Gyawali S., Techato K., Monprapussorn S., Yuangyai C. 2013. Integrated land use and water quality enviromental base land use planning for U-Tapao River basin, Thailand. Procedia - Social and Behavioral Sciences.

7. Heineman M., Eichenwald Z., Gamache M., Miner 
R. 2013. A comprehensive water quality model of boston's drainage systems. Proceedings of the World Environmental and Water Resources Congress, 2013.

8. Huang J., Zhan J., Yun H., Wu F., Deng D.X. 2013. Evaluation of the impact of land use on water quality a case study in the chaohu lake basin. The Scientific World Journal.

9. Inez W., Brierley G., Trowsdale S. 2009. The use of system dynamics simulation in water resources management. Journal Water Resources Management.

10. Hanh M.P.T., Sthiannopkao S., Dang T.B., Kim K.W. 2011. Developmemt of water quality indexes to identify pollutans in vietnam's surface water. Journal of Enviromental Engineering.

11. Mirchi A., Madani K., Watkins J.D., Ahmad S. 2012. Synthesis of system dynamics tools for holistic conceptualization of water resources problems. Journal Water Resources Manage.

12. Namara I., Hartono D.M., Rarasat A.D., Muhammad L.T. 2017. Risk analyze: Management water quality cisadane river by project approach. Malaysian Journal of Industrial Techonology.

13. Namara I., Hartono D.M., Latief Y., Moersidik S.S. 2018. Institution and legal aspect based river water quality management. International Journal of Engineering and Technology (UAE), 7(3).
14. Namara I., Hartono D.M., Latief Y., Moersidik S.S. 2020. The effect of land use change on the water quality of Cisadane River of the Tangerang City. Journal of Engineering and Applied Sciences, 15(9).

15. Nian Y.Y., Li X., Zhou J., dan Xiali H.U. 2014. Impact of land use change on water resource allocation in the middle reaches of the Hiehe River basin in Northwastern China. Journal of Arid Land.

16. Ray A.P., Kirshen P.H., Vogel R. 2010. Integrated Optimazion of Dual Quality Water and Waste Water System. ASCE Libarry.

17. Sanchez J.D.F. 2013. A Guide to the Project Management Body of Knowledge, PMI, Inc., 5.

18. Soesilo T.E.B., Mahawan K. 2014. Permodelan System Dynamics. LPFEUI. Jakarta.

19. Sterman J.D. 2004. Bussines Dynamics System Thingking and Modelling for A Complex World. International Edition. Mc Grwa Hill.

20. Tong S.T.Y., Chen W. 2001. Modeling the relationship between land use and surface water quality. Journal of Enviromental Management.

21. Suwari, Riani E., Pramudya B., dan Ita D. 2011. Model dinamik pengendalian pencemaran air kali Surabaya. Jounal of Bumi Lestari.

22. Zhile C., Wei S. 2014. Application of system dynamics to water security research, Water Resource Management. 